\title{
TEORI EVOLUSIONISME DILIHAT DARI SUDUT PANDANG ANTROPOLOGI HUKUM
}

\author{
ROBITA ISLAMI \\ Email: islamirobi3@gmail.com \\ No BP: 2110003600323 \\ Universitas Ekasakti Padang
}

\section{A. PENDAHULUAN}

Pemikiran dasar evolusionisme adalah bahwa ada suatu kepastian dalam tata tetib perkembangan, yang melintasi kebudayaan dengan kecepatan yang agak kecil agak besar (Baal,1988; 114). Sebagai contoh dalam hal perkawinan, Edward Watermarck bahwa ada hubungan analogis antara hewan dan manusia. Khususnya pada jenis burung, telah ada pemilihan keturunan, bahkan burung jantan juga memelihara anak-anaknya. Hal ini mengidentifikasiakn bahwa masa silam perkawinan manusia pun tidak tidak campur aduk, malinkan telah ada proses yang beradap. Perkawinan masa lalu telah berlangsung lama, pada masa itu telah memikirkan hubungan seksual, dan kerenanya memerlukan perawatan. Perkawinan besar kemungkinananya berupa warisan.

Kata antropologi berasal dari dua kata bahasa Yunani yaitu "anthropos" yang berarti manusia dan "logos" yang berarti ilmu. Secara harfiah, antropologi dapat didefinisikan sebagai suatu keilmuan yang mempelajari manusia dari segi keanekaragaman fisik, serta kebudayaannya. Antropologi merupakan suatu cabang ilmu sosial yang membahas mengenai budaya masyarakat suatu etnis. Antropologi muncul karena adanya ketertarikan dari orang Eropa yang melihat budaya, ciri-ciri fisik dan adat istiadat yang berbeda.

Obyek dari antropologi adalah manusia, kebudayaan serta perilakunya. Obyek antropologi dengan kata lain menyangkut semua manusia dimanapun dan kapanpun. Tujuan dari antropologi adalah untuk membangun masyarakat dengan mempelajari perilaku, bagaimana 
manusia dapat bermasyarakat dalam suku bangsa dan budaya manusia. Antropologi memadukan secara integratif tujuan biologi dan sosio-budaya dalam kehidupan.

Teori Evolusionisme Deterministik dapat dikatakan sebagai teori tertua di deretan teori antropologi. Teori ini dikembangkan oleh Lewis Henry Morgan dan Edward Burnet Tylor. Teori ini muncul dari anggapan adanya hukum universal yang mengendalikan perkembangan semua kebudayaan manusia. Berdasarkan teori ini setiap kebudayaan mengalami fase-fase atau evolusi.

Lewis Henry Morgan (1818-1881) menggambarkan proses evolusi masyarakat dan kebudayaan dengan delapan tahap evolusi universal yang dituangkan dalam karyanya dengan judul Ancient Society. Delapan tingkat evolusi tersebut adalah zaman liar, zaman liar madya, zaman liar muda, zaman barbar tua, zaman barbar madya, zaman barbar muda, zaman peradaban purba dan zaman peradaban masa kini.

\section{B. PEMBAHASAN}

Pada abad ke sembilan belas, dalam masyarakat Eropa mengemukakan sebuah paradigma (cara pandang) yang memandang bahwa gejala-gejala yang timbul dari alam, masyarakat dan kebudayaan yang ada dalam komunitas manusia dapat dilihat dan dipikirkan secara rasional. Cara pandang yang secara tidak langsung mengkritik perilaku masyarakat Eropa Barat yang mengembalikan segala sesuatunya ke kitab suci ini kemudian dikenal dengan teori evolusi kebudayaan. Paradigma ini dipahami sebagai pandangan yang menyatakan bahwa ada kepastian dalam tata tertib perkembangan yang melintasi sejarah kebudayaan dengan kecepatan yang pelan tetapi pasti. Selanjutnya, dimulailah pergumulan dogma-dogma agama yang telah sekian lama mengakar di tengah-tengah masyarakat dengan cara pandang baru yang sepenuhnya berbeda dan asing bagi masyarakat Eropa Barat saat itu. 
Paradigma evolusi kebudayaan yang ingin mengganti model dogmatis agama yang telah mendarahdaging di Eropa Barat dalam memandang kebudayaan manusia ini dikemukakan pertama kali oleh Edward Burnett Tylor (1832-1917), seorang ahli antropologi yang berasal dari Inggris. Persinggungan Tylor dengan hal-hal yang berkaitan dengan kebudayaan dimulai ketika ia menempuh pendidikan kesusastraan dan peradaban Yunani dan Romawi klasik. Ketertarikan seputar kebudayaan ini membuatnya sangat menyukai ilmu arkeologi yang memang mengambil objek kajian terhadap benda-benda peninggalan masa lampau. Ketertarikan ini terus tumbuh subur seiring didapatnya kesempatan untuk melakukan suatu perjalanan menyusuri Afrika dan Asia hingga membuatnya tertarik untuk membaca naskah-naskah etnografi yang mengisahkan tentang masyarakat yang ada di kedua benua tersebut. Setelah mendapat pengakuan sebagai seorang pakar arkeologi, Tylor diajak serta mengikuti ekspedisi Inggris untuk mengungkap benda-benda arkeologis peninggalan beragam suku yang ada di Meksiko.

Kepiawaian Tylor dalam kajian kebudayaan membuatnya diangkat sebagai guru besar di Harvard University. Menurut Tylor, kebudayaan merupakan keseluruhan yang kompleks, yang di dalamnya terkandung pengetahuan, kepercayaan, kesenian, moral, hukum, adat istiadat, dan kemampuan-kemampuan lain yang didapat seseorang sebagai anggota masyarakat. Ada banyak tulisan yang berhasil ia sumbangkan bagi kajian kebudayaan, utamanya untuk semakin menguatkan dan menyebarkan pandangannya mengenai teori evolusi kebudayaan. Salah satu bukunya berjudul Researches into the Early History of Mankind, semakin menguatkan keteguhannya mengenai teori evolusi kebudayaan yang memang telah sekian lama ia perjuangkan. Dalam buku yang ditulis pada tahun 1871 ini, Tylor mengungkapkan tujuan sesungguhnya dari kajian kebudayaan yang dilakukan oleh seorang ahli antropologi. Menurutnya, kajian antropologi adalah untuk mempelajari aneka ragam kebudayaan sebanyak- 
banyaknya, kemudian dicarikan unsur-unsur persamaannya, selanjutnya dilakukan proses klasifikasi. Dengan cara dan tahapan seperti ini, menurut Tylor, maka akan tampak kemudian adanya evolusi kebudayaan manusia yang terdiri dari beragam tingkatan perkembangan yang masing-masing memiliki karakteristik tersendiri.

Hal yang telah dipaparkan oleh Tylor dalam buku di atas, sepertinya diimplementasikannnya dalam bukunya yang lain berjudul Primitive Culture: Researches into the Development og Mythology, Phylosophy, Religion, Language Art and Custom. Dalam buku yang ditulis tahun 1874 ini, Tylor memaparkan bahwa kebudayaan manusia dalam sejarah evolusinya berjalan melalui tiga tahap perkembangan yang masing-masing tahapan dibedakan berdasarkan unsur ekonomi dan teknologi yang mereka gunakan. Ketiga tahapan perkembangan kebudayaan manusia tersebut adalah savagery, barbarian dan civilization.

Pada tahap pertama (savagery), manusia hanya bertahan hidup dengan cara berburu dan meramu dengan menggunakan peralatan yang mereka ciptakan dari benda-benda yang ada di sekitar mereka, seperti kayu, tulang dan batu. Berkembang kemudian menuju tahap kedua (barbarian) yang ditandai dengan mulainya manusia mengenal cocok tanam. Karena mulai memahami cara menanam, maka mereka berpikir untuk menjaga agar tanaman tersebut dapat dipelihara dan dimanfaatkan hasil sehingga mereka mulai hidup menetap di sekitar tanaman tersebut. Tahapan kedua ini juga ditandai dengan perkembangan peralatan mereka dari yang sebelumnya hanya terbuat dari kayu, batu dan tulang menjadi terbuat dari logam. Berkembang kemudian menjadi tahap ketiga (civilization) atau peradaban yang ditandai dengan pengenalan manusia dengan tulisan, kehidupan perkotaan dan kemampuan mereka membangun bangunanbangunan besar yang sebelumnya belum pernah ada. Untuk dapat mencapai semua itu, tentunya 
manusia memerlukan ilmu pengetahuan dan peralatan-peralatan yang canggih serta yang tidak boleh terlupakan adalah memiliki kompleksitas sistem organisasi sosial.

Setelah cukup lama berinteraksi dengan paparan evolusi kebudayaan Tylor, maka dunia kajian kebudayaan kemudian berjumpa dengan paradigma yang sama tetapi dikemukakan oleh orang yang berbeda. Paparan-paparan teori evolusi kebudayaan sebagaimana yang dikemukakan oleh Tylor sebelumnya kemudian dilanjutkan oleh Lewis Henry Morgan, seorang antropolog Amerika. Pada awalnya Morgan dikenal sebagai seorang ahli hukum, akan tetapi karena cukup lama berinteraksi dan tinggal dengan suku-suku Indian Iroquois di New York, ia kemudian banyak mengenal kebudayaan suku asli benua Amerika ini. Hasil kajian etnografinya mengenai suku Indian tempat ia lama tinggal kemudian diterbitkan dalam bentuk buku berjudul League of the Ho-de-no-Sau-nie or Iroquois. Dalam buku ini, Morgan memaparkan susunan kemasyarakatan dan kekerabatan yang ada dalam masyarakat suku Indian ini yang dilakukan berdasarkan pada gejala kesejajaran yang seringkali ada dalam sistem istilah kekerabatan dan sistem kekerabatan.

Sebagai seorang yang melakukan kajian kebudayaan sekaligus juga hidup dalam era perkembangan pesat teori evolusi kebudayaan, Morgan mengambil peranannya dalam sustainibitas pandangan-pandangan yang dikemukakan oleh Tylor. Bahkan, lebih dari itu ia juga sangat dikenal sebagai orang mengembangkan apa yang sudah dirintis oleh Tylor sebelumnya seiring dengan banyaknya kajiannya terhadap kebudayaan Indian. Sebagai aplikasi dari dukungan dan upaya pengembangannya terhadap teori evolusi kebudayaan, Morgan kemudian menghasilkan sebuah buku berjudul Ancient Society yang menggambarkan proses evolusi masyarakat dan kebudayaan manusia. 
Menurut Morgan, sebagaimana yang dikemukakannya dalam buku yang ditulis tahun 1877 tersebut di atas, semua bangsa di dunia telah atau sedang menyelesaikan proses evolusinya yang melalui delapan tingkatan, yaitu:

1. Era liar tua atau zaman paling awal sampai manusia menemukan api,

2. Era liar madya atau sejak menemukan api sampai manusia menemukan senjata,

3. Era liar muda atau sejak menemukan senjata sampai pandai membuat tembikar dan masih berprofesi sebagai pemburu,

4. Era barbar tua atau zaman sampai manusia mulai beternak dan bercocok tanam,

5. Era barbar madya atau zaman sampai manusia pandai membuat peralatan dari logam, era barbar muda atau zaman sampai manusia mengenal tulisan, era peradaban purba, dan era masa kini.

Seiring dengan perjalanan waktu, persinggungan teori evolusi dengan beragam realitas dalam perkembangannya terus mendapatkan tanggapan dari beragam pihak. Setidaknya tanggapantanggapan yang mengemuka terhadap pandangan-pandangan kebudayaan teori evolusi dapat dibedakan menjadi dua macam. Pandangan pertama menganggap bahwa pandangan-pandangan yang diajukan teori evolusi melalui dua tokoh utamanya, Tylor dan Morgan, memiliki beragam kelemahan yang harus diperbaiki. Pandangan ini tidak menolak sepenuhnya apa yang dikemukakan dua tokoh utama generasi awal teori evolusi tersebut, tetapi tetap menerima beberapa bagian yang mereka anggap dapat diterima dan mengganti beberapa hal yang mereka anggap keliru serta menggantinya dengan model lain. Sedangkan kelompok kedua adalah menolak sepenuhnya segala pandangan yang diajukan oleh teori evolusi dalam melihat kebudayaan manusia. Kelompok kedua ini di kemudian hari dikenal dengan 'difusi kebudayaan' 
sebagai jawaban atas beragam ketidaksetujuan mereka terhadap pandangan-pandangan kebudayaan evolusi.

Setelah melakukan beragam penelaahan terhadap pandangan-pandangan kebudayaan Tylor dan Morgan dalam memandang kebudayaan manusia, generasi selanjutnya teori evolusi memunculkan dua teori evolusi baru. Pertama, teori evolusi kebudayaan universal yang dikemukakan oleh Leslie White dan teori evolusi kebudayaan multilinier yang diajukan oleh Julian Steward. Teori pertama disebut demikian karena paparan teori yang dikemukakan White tersebut mencakup seluruh budaya yang ada di dunia dan tidak diperuntukkan untuk budaya tertentu saja. Untuk menjawab beragam keritikannya terhadap paparan-paparan evolusi kebudayaan yang diajukan oleh Tylor dan Morgan sebelumnya, White mengemukakan teori evolusinya sendiri berdasarkan sebuah kriteria yang sama sekali baru dan belum pernah dikemukakan oleh dua pendahulunya tersebut. Kriteria ini baginya merupakan satu hal yang memungkinkan sebuah teori evolusi menjadi bersifat objektif dan tidak seperti model yang dikemukakan oleh Tylor dan Morgan yang menurutnya sangat subjektif. Kriteria yang diajukan oleh White tersebut adalah berupa energi, karena menurutnya pada dasarnya setiap kebudayaan adalah sistem yang melakukan transformasi energi. Dengan menggunakan energi sebagai standar atau tolok ukur dalam melakukan kajian terhadap fase perkembangan suatu kebudayaan manusia, dimana hal ini tidak ada dalam teori Morgan, maka akan dapat diukur sampai sejauh mana tingkat evolusi yang ada dalam sebuah masyarakat dapat ditentukan secara kuantitatif.

Lebih lanjut, untuk lebih mensistematiskan model evolusi kebudayaannya yang baru ini, White mengemukakan sebuah rumusan yang dapat memudahkan dalam melakukan kajian. White menyebutnya sebagai sebuah 'hukum' evolusi kebudayaan, yaitu $\mathrm{C}=\mathrm{E} \times \mathrm{T}$. Penjelasannya 
adalah C merupakan kebudayaan (culture), E adalah energi (energy) sedangkan $\mathrm{T}$ adalah teknologi (technology). Sebuah kebudayaan yang ada dalam sebuah komunitas masyarakat manusia adalah dampak atau hasil hasil dari pemakaian atau penggunaan energi dan teknologi yang mereka gunakan dalam kehidupan mereka pada fase-fase perkembangannya. Dengan rumusan yang disebutnya sebagai 'hukum' evolusi kebudayaan ini, White sampai pada sebuah kesimpulan bahwa terjadinya sebuah evolusi kebudayaan dalam sebuah komunitas merupakan hasil dari mengemukanya perubahan dalam sistem yang melakukan transformasi energi dengan bantuan teknologi yang ada saat itu. Dalam teori mengenai evolusi kebudayaan ini terdapat beberapa konsep baru yang diketengahkan White, yaitu thermodinamika (sistem yang melakukan transformasi energi), energi dan transformasi.

Teori kedua diartikan Steward sebagai suatu metodologi yang digunakan untuk mengkaji perbedaan dan kesamaan suatu budaya dengan cara memperbandingkan antara tuntunantuntunan perkembangan kebudayaan yang sejalan yang biasanya terdapat di tempat-tempat yang terpisah. Seperti White yang menganggap bahwa pandangan-pandangan yang dikemukakan oleh dua pendahulunya mengenai kebudayaan yang memiliki kelemahan pada ketiadaan standar dalam menentukan setiap fase perkembangan kebudayaan manusia, Steward pun melakukan hal yang sama. Meskipun demikian, titik fokus kritikan Steward terhadap model teori evolusi terdahulu bukan pada standar yang digunakan, tetapi pada data yang digunakan oleh Tylor dan Morgan sehingga keduanya sampai pada kesimpulan yang memunculkan pandanganpandangannya mengenai evolusi kebudayaan yang telah sekian lama bercokol dalam khazanah ilmu antropologi. 
Setelah melalui kajian yang memakan waktu cukup lama, Steward sampai pada suatu kesimpulan bahwa data yang digunakan oleh kedua tokoh yang merupakan generasi awal teori evolusi tersebut tidak berasal dari hasil penelitian lapangan yang dilakukan secara benar. Untuk membuktikan fokus kritikannya ini, Steward melakukan suatu penelitian terhadap salah satu suku Indian yang mendiami suatu kawasan di Amerika Serikat. Dari penelitiannya ini, Steward mendapatkan sebuah kesimpulan yang berbeda dari paparan dua pendahulunya tersebut sekaligus juga semakin menguatkan kritikannya sebagaimana di atas, dimana ternyata suku Indian tersebut tidak lagi mengalami evolusi sebagaimana yang diungkapkan oleh Morgan di atas.

Terdapat satu faktor, menurut Steward berdasarkan penelitian kebudayaannya, yang membuat suatu suku Indian tidak lagi mengalami evolusi dan dapat pula terjadi pada suku-suku lainnya. Dari kajian yang dilakukannya, Steward menyimpulkan bahwa tidak lagi berjalannya perkembangan kebudayaan dalam sebuah komunitas, dalam konteks penelitiannya adalah suku Indian, disebabkan karena suku tersebut telah mengalami penyesuaian atau beradaptasi dengan lingkungan tempat mereka tinggal dan menetap dalam keseharian mereka. Berdasarkan kesimpulan ini, maka Steward mengajukan sebuah teori baru dalam khazanah kajian budaya, khususnya dalam rangkaian teori evolusi budaya, yaitu teori evolusi multilinier.

Menurut teori multilinier, terjadinya evolusi kebudayaan berhubungan erat dengan kondisi lingkungan, dimana setiap kebudayaan memiliki culture core, berupa teknologi dan organisasi kerja. Dengan demikian, terjadinya evolusi dalam sebuah kebudayaan ditentukan oleh adanya interaksi yang terjalin antara kebudayaan tersebut dengan lingkungan yang ada di dalamnya. Seperti halnya teori yang dikemukakan oleh White di atas, teori multilinier juga 
memunculkan konsep-konsep baru yang belum pernah ada sebelumnya, yaitu lingkungan, culture core, adaptasi dan organisasi kerja.

Tokoh lainnya yang tidak kalah juga perlu mendapat perhatian dalam perbincangan mengenai teori evolusi, khususnya setelah dua tokoh utama pada generasi awal, adalah V. Gordon Childe yang merupakan arkeologis Inggris. Berbeda dengan White dan Steward yang begitu kokoh dengan pendirian evolusi mereka, para pengamat menilai Childe seringkali goyah dengan pendirian evolusinya. Untuk memaparkan pandangannya mengenai evolusi budaya, Childe menggunakan rekaman arkeologis untuk menunjukkan bahwa apa yang dikemukakan dalam teori evolusi menunjukkan kenyataan yang sebenarnya dalam komunitas manusia.[16] Dari benda-benda yang dihasilkan dari penggalian arkeologis yang dilakukannya selama beberapa waktu menunjukkan sesuatu yang semakin menguatkan pandangan evolusi, bahwa kemajuan teknis yang dramatis dalam sejarah manusia berupa budidaya tumbuhtumbuhan dan hewan, irigasi, penemuan logam dan lain sebagainya terbukti telah membawa perubahan revolusioner dalam keseluruhan jalinan kehidupan kultural yang dilakoni oleh manusia.

Benda-benda arkeologis yang ditemukan Childe makin menguatkan teori evolusi bahwa keseluruhan pola perubahan yang terjadi dalam setiap fase perkembangan kebudayaan manusia menunjukkan perubahan yang bersifat evolutif dan progresif. Hal ini ditunjukkan dengan adanya perubahan atau perkembangan dari satu fase ke fase selanjutnya, seperti dari pemburu-peramu yang berpindah-pindah (nomadik) yang berada pada masa Paleolitik menjadi seorang manusia yang bercocok tanam (holtikulturalis) yang tidak lagi nomadik atau sudah menetap di satu tempat sebagai komunitas kempal dalam masa Neolitik. 


\section{PENUTUP}

Teori evolusi merupakan salah satu teori yang di gunakan dalam melihat fenomena perubahan budaya dalam pandangan antropologi. Teori evolusi melihat perubahan budaya terjadi karena adanya perkembangan daya fikir manusia yang mampu merubah beberapa sisi kebuadaan.

E.B Tylor ia juga berpendirian bahwa bentuk religi paling tua adalah penyembahan kepada roh-roh yang merupakan personifikasi dari jiwa-jiwa orang-orang yang telah meninggal, terutama nenek moyangnya. Bentuk religi yang tertua ini pada semua bangsa didunia akan berevolusi kebentuk religi yang menurut spencer merupakan tingkat evolusi yang lebih kompleks dan berdiferensiasi, yaitu penyembahan kepada dewa- dewa, seperti dewa kejayaan, dewa kebijaksanaan, dewa perang, dewi kecantikan, dan sebagainya.

Implementasi dari teori evolusi ini pada bidang pertanian terbukti dengan adanya perubahan dalam proses pembajakan sawah, pada masa terdahulu petani membajak sawah gengan menggunakan kayu yang dibentuk menjadi runcing yang kemuddian di bantuk dengan tenaga hewan. Dan saat ini kayu dan tenaga hewan diganti oleh tenaga yang sangat modern dengan menggunakan mesin pembajak. Perubahan ini terjdi karena adanya perkembangan kemmpuan berfikir manusia yang melahirkan satu bentuk kebubdayaan baru.

Kelebihan teori evolusi adalah digunakannya standar atau tolok ukur untuk melihat adanya perbedaan dalam setiap fase perkembangan kebudayaan, sebagaimana yang dikemukakan oleh White dengan standar energinya dan Steward dengan adaptasi lingkungannya.

\section{DAFTAR PUSTAKA}

Darmini Roza dan Laurensius Arliman S, Peran Pemerintah Daerah Di Dalam Melindungi Hak Anak Di Indonesia, Masalah-Masalah Hukum, Volume 47, Nomor 1, 2018. https://doi.org/10.14710/mmh.47.1.2018.10-21 
Laurensius Arliman S, Peranan Metodologi Penelitian Hukum di Dalam Perkembangan Ilmu Hukum di Indonesia, Soumatera Law Review, Volume 1, Nomor 1, 201. http://doi.org/10.22216/soumlaw.vli1.3346.

Laurensius Arliman S, Peran Badan Permusyawaratan Desa di Dalam Pembangunan Desa dan Pengawasan Keuangan Desa, Padjadjaran Journal of Law, Volume 4, Nomor 3, 2017. https://doi.org/10.15408/jch.v4i2.3433.

Laurensius Arliman S, Penanaman Modal Asing Di Sumatera Barat Berdasarkan UndangUndang Nomor 25 Tahun 2007 Tentang Penanaman Modal, Supremasi Hukum, Volume 1, Nomor 1, 2018. http://dx.doi.org/10.36441/hukum.v1i01.102.

Laurensius Arliman S, Memperkuat Kearifan Lokal Untuk Menangkal Intoleransi Umat Beragama Di Indonesia, Ensiklopedia of Journal, Volume 1, Nomor 1, 2018, https://doi.org/10.33559/eoj.v1i1.18.

Laurensius Arliman S, Perkawinan Antar Negara Di Indonesia Berdasarkan Hukum Perdata Internasional, Kertha Patrika, Volume 39, Nomor 3, 2017, https://doi.org/10.24843/KP.2017.v39.i03.p03.

Laurensius Arliman S, Partisipasi Masyarakat Di Dalam Pengelolaan Uang Desa PascaUndangUndang Nomor 6 Tahun 2014 Tentang Desa, Jurnal Arena Hukum, Volume 12, Nomor 2, 2019, https://doi.org/10.21776/ub.arenahukum.2019.01202.5.

Laurensius Arliman S, Mewujudkan Penegakan Hukum Yang Baik Di Negara Hukum Indonesia, Dialogica Jurnalica, Volume 11, Nomor 1, 2019, https://doi.org/10.28932/di.v11i1.1831.

Laurensius Arliman S, Mediasi Melalui Pendekatan Mufakat Sebagai Lembaga Alternatif Penyelesaian Sengketa Untuk Mendukung Pembangunan Ekonomi Nasional, UIR Law Review, Volume 2, Nomor 2, 2018, https://doi.org/10.25299/uirlrev.2018.vol2(02).1587

Laurensius Arliman S, Peranan Filsafat Hukum Dalam Perlindungan Hak Anak Yang Berkelanjutan Sebagai Bagian Dari Hak Asasi Manusia, Doctrinal, Volume 1, Nomor 2,2016.

Laurensius Arliman S, Ni Putu Eka Dewi, Protection of Children and Women's Rights in Indonesiathrough International Regulation Ratification, Journal of Innovation, Creativity and Change Volume 15, Nomor 6, 2021.

Laurensius Arliman S, Gagalnya Perlindungan Anak Sebagai Salah Satu Bagian Dari Hak Asasi Manusia Oleh Orang Tua Ditinjau Dari Mazhab Utilitarianisme, Jurnal Yuridis, Volume 3, Nomor 2, 2016, http://dx.doi.org/10.35586/.v3i2.180.

Laurensius Arliman S, Tantangan Pendidikan Kewarganegaraan Pada Revolusi 4.0, Jurnal Ensiklopedia Sosial Review, Volume 2, Nomor 3, 2020. 